\title{
Pengaruh Globalisasi Terhadap Nilai-Nilai Budaya Pada Rumah Tradisional Masyarakat Sade Lombok Tengah
}

\author{
Hendri Adrian', Wayan Resmini²
}

${ }^{1}$ Pendidikan Pancasila dan Kewarganegaraan, Universitas Muhammadiyah Mataram, hendri.adrian12@gmail.com

${ }^{2}$ Pendidikan Pancasila dan Kewarganegaraan, Universitas Muhammadiyah Mataram, wayanresmini@ymail.com

\begin{tabular}{|c|c|}
\hline \multicolumn{2}{|c|}{ INFO ARTIKEL } \\
\hline Riwayat & Irtikel: \\
\hline $\begin{array}{l}\text { Diterima: } \\
2018 \\
\text { Disetujui: } \\
2018\end{array}$ & $\begin{array}{l}\text { 20-Agustus- } \\
\text { 10-September- }\end{array}$ \\
\hline
\end{tabular}

\section{Kata Kunci:}

pengaruh

globalisasi

nilai budaya

rumah tradisional

sade

\section{A. LATAR BELAKANG}

Indonesia sebagai Negara berkembang yang masyarakatnya masih primitive, namun perkembangan ilmu pengetahuan dan tekhnologi semakin mendorong upaya-upaya pembaharuan hasil-hasil teknologi. Tekhnologi mempunyai pengaruh yang sangat besar terhadap globalisasi. Globalisasi menyentuh seluruh aspek penting kehidupan. Globalisasi menciptakan berbagai tantangan dan permasalahan baru yang harus dijawab, dipecahkan dalam upaya untuk memanfaatkan globalisasi untuk kehidupan. Karena globalisasi juga

\begin{abstract}
Abstrak: Rumah Tradisional masyarakat suku sasak yang ada di pulau Lombok masih menjaga keaslian dan memperkuat Lanti (Belulut) dengan kotoran kerbau. Menjaga nilainilai yang ada dalam kepercayaan turun-temurun dari nenek moyang, namun seiring perkembangan zaman dan globalisasi telah mempengaruhi keaslian rumah dan nilai-nilai budaya masyarakat Sade. Tujuan artikel ini adalah untuk mengetahui pengaruh yang ditimbulkan globalisasi terhadap nilai-nilai budaya pada rumah teradisional masyarakat Sade Lombok Tengah dan masalah-masalah yang ditimbulkan oleh gelobalisasi terhadap nilainilai budaya pada rumah tradisional masyaraakt Sade Lombok Tengah. Metode Penelitian adalah metode kulitatif dengan pendekatan deskriptif. Penelitian ini dilakukan di Dusun Sade, Desa Rambitan Kecamatan Pujut Kabupaten Lombok Tengah, informan dalam penelitian ini adalah masyarakat, tokoh adat, dan pemerhati budaya. Metode pengumpulan data menggunakan observasi, wawancara, dan dokumentasi dengan teknik analisis data menggunakan model analisis interaktif. Berdasarkan hasil penelitian yang diperoleh dilapangan bahwa pengaruh globalisasi terhdap nilai-nilai budya pada masyarakat sudah mulai terpengaruh dimana nilai-nilai atau kebiasaan yang sudah dilakukan oleh masyarakat setempat yang merekat dan memperkuat lantai menggunakan kotoran kerbau. Juga terlihat dari bentuk bangunan rumah masyarakat yang sudah banyak meniggalkan keaslian dari rumah teradisional tersebut. Hal ini membuat nilai-nilai budaya pada rumah tradisional masyarakat sedikit mengalami perubahan.
\end{abstract}

Abstract: Traditional House of Sasak tribe people in the island of Lombok still keep the authenticity and strengthen Lanti (Belulut) with Buffalo dung. Maintaining the values that exist in the hereditary belief of the ancestors, but as the development of the Times and globalization has influenced the authenticity of the home and cultural values of Sade society. The purpose of this article is to find out the influence of globalization on cultural values in the houses of the communities of the Sade Central Lombok community and the problems posed by the globalization of cultural values in Traditional home of the people of Aakt Sade central Lombok. The research method is the method of qualitative with a descriptive approach. This research was conducted in Sade Hamlet, a village of Rambitan district of Pujut Central Lombok Regency, the informant in this research is a community, indigenous people, and cultural observers. Data collection methods using observations, interviews, and documentation with data analysis techniques using interactive analysis models. Based on the research obtained in the field that the influence of globalization in the values of the culture of the community has begun to be affected where the values or habits that have been done by the local community that is blocking and strengthening Floor using buffalo dung. Also seen from the shape of the building community House that has a lot to leave the originality of the house. This makes cultural values at traditional homes of society a little changed. memiliki penggaruh yang penting bagi kehidupan masyarakat Indonesia.

Kehidupan masyarakat Indonesia yang semakin berkembang sesuai dengan kemajuan zaman, diiringi dengan perubahan kehidupan masyarakat. Contoh sederhana dengan tekhnologi internet, parabola dan TV, orang dibelahan bumi manapun akan dapat mengakses berita dari belahan dunia yang lain secara cepat. Sehingga akan menjadi sebuah permasalahan apabila pengaruh dari penggunaan media mengubah masyarakat baik dari segi budaya, sifat dan nilai-nilai kemasyarakatan. Sehingga masyarakat pada umumnya 
di Indonesia dan khususnya di wilayah Lombok Tengah juga mengalami dampak dari perkembangan ilmu pengetahuan seperti internet. Dimana internet adalah salah satu akses untuk masuk dalam pengaruh globalisasi.

Tidak menutup kemungkinan efek dari perkembangan tekhnologi yang mempermudah masyarakat untuk dirasuki oleh era globalisasi yang merajalela. Dapat merubah berbagai segi nilai-nilai budaya suatu masyarakat. Harus diakui, aktor utama dalam proses globalisasi masa kini adalah negara-negara maju. Mereka berupaya mengekspor nilai-nilai lokal di negaranya untuk disebarkan ke seluruh dunia sebagai nilai-nilai global[1]. Baik itu berupa dari segi tempat tinggal, penampilan, keagamaan maupun kehidupan sehari-hari masyarakat. Sehingga sangat penting bagi kita khususnya peneliti untuk mengetahui penyebab adannya perubahan pada masyarakat. Oleh karana itu akibat dari kemajuan teknologi yang semakin cangih, akan mengakibatakan berbagi tantangan, sehingga akan mengakibatkan terjadinya perubahan nilai-nilai budaya. Globalisasi menimbulkan berbagai masalah dalam bidang kebudayaan,misalnya : hilangnya budaya asli suatu daerah atau suatu negara, terjadinya erosi nilainilai budaya, menurunnya rasa nasionalisme dan patriotisme, hilangnya sifat kekeluargaan dan gotong royong, kehilangan kepercayaan diri, gaya hidup yang tidak sesuai dengan adat kita[2].

Nilai-nilai budaya itu sangat penting bagi kehidupan masyarakat. Sehingga ingin mengetahui dampak yang ditimbulkan oleh giobalisasi tehadap nilai-nilai budaya padapada masyarakat. Khususnya pada masyarakat di Dusun Sade Desa Rambitan Kecamatan Pujut Kabupaten Lombok Tengah. Karena Dusun Sade Desa Rambitan adalah salah satu objek wisata kebudayaan yang masih ada sampai saat ini. Namun berbagai perubahan terlihat dari efek perkembangan tekhnologi pada segi budaya dan kebiasaan masyarakat. Lihat saja di masyarakat Bali, perubahan terjadi karena kontak budaya antar negara yang dimaknai adanya dialektika nilai-nilai baru dengan nilai-nilai lama yang saling mendominasi, yang memungkinkan terjadinya homogenisasi dan neoliberalisasi pada seluruh aspek kehidupan termasuk nilai-nilai budaya lokal yang selama ini menjadi pegangan masyarakat Bali[3].

Di dalam hal ini kebudayaan erat hubungannya antara kebudayaan dengan masyarakat dinyatakan dalam kalimat, "masyarakat adalah orang-orang yang hidup bersama dan menghasilkankebudayaan, sehingga tidak ada masyarakat yang tidak menghasilkan kebudayaan. Sebaliknya tidak ada kebudayaan tanpa masyarakat sebagai wadah dan pelakunya". Kebudayaan adalah sarana hasil karya, rasa, dan cipta masyarakat[4].

Menyikapi prolematika itu, dibutuhkan strategi yang tepat agar budaya lokal tidak semakin tergerus oleh budaya asing dan secara perlahan berpotensi melenyapkan. Strategi yang bisa dijalankan adalah pembangunan jati diri bangsa untuk memperkokoh identitas kebangsaan, pemahaman falsafah budaya kepada seluruh kalangan masyarakat, penerbitan peraturan daerah yang melindungi budaya lokal, dan memanfaatkan teknologi informasi untuk mengenalkan budaya lokal ke masyarakat dunia[5].

Oleh karena itu sangat penting bagi masyarakat untuk memanfaatkan perkembangan zaman untuk segala hal yang dapat memajukan diri sendiri, teman dan Negara ke arah yang positif. Sehingga sangat penting untuk kita mengetahui berbagai efek dari globalisasi sebagai acuan untuk memperbaikinya dan memanfaatkan sesuai dengan nilai-nilai budaya di daerah masing-masing. Seperti pulau Lombok yang begitu dikenal dari segi pariwisata, lama-lama akan menghilang apabila dipengaruhi dengan budaya yang tidak sesuai dengan kebiasaan masyarakat. Sehingga yang terjadi adalah akan tidak adanya ketertarikan dan keunikan dari daerah Lombok pada kebudayaan yang menjadi daya tarik wisatawan. Khususnya di Dusun Sade Desa Rambitan Kecamatan Pujut Kabupaten Lombok Tengah yang dikenal bahwa Dusun Sade itu sebagai objek wisata yang ada di pulau Lombok, yang masih kental dengan budaya masayarakat sasak masa lalu, yang masih memegang kepercayan nenek moyang, dan Dusun Sade juga yang daerah satu-satunya yang masih mengunakan bangunan rumah sasak pada tempo dulu, yang dimana setiap ruangan dan di dalam rumah tersebut mempunyai makna dan filosofi yang masih dipercaya sampai saat ini oleh masyarakat Sasak khususnya Dusun Sade.

Tujuan dari penelitian ini adalah untuk mengetahui seberapa besar pengaruh yang ditimbulkan globalisasi terhadap nilai-nilai budaya pada rumah teradisional masyarakat Dusun Sade dan masalah-masalah yang ditimbulkan oleh gelobalisasi terhdap nilai-nilai budya pada rumah tradisional masyaraakt Dusun Sade Desa Rambitan Kecamatan Pujut Lombok Tengah.

\section{B. METODE PENELITIAN}

\section{Metode yang Digunakan}

Metode penelitian pada dasarnya merupakan cara ilmiah untuk mendapatkan data, dengan tujuan dan kegunaan tertentu. Metode penelitian dapat dibedakan menjadi dua metode yaitu, metode penelitian kuntitatif dan metode penelitian kulitatif[6].

Metode kuntitatif dapat diartikan sebagai metode penelitian yang berlandaskan pada filsafat possitivisme, digunakan untuk meneliti pada populasi atau sampel tertentu[7]. Tehnik pengambilan sampel pada umumnya dilakukan secara random, pengumpulan data menggunakan instrument penelitian, analisis data bersifat kuantitatif/statistik dengan tujuan untuk menguji hipotesis yang telah ditetapkan.

Penelitian kulitatif adalah penelitian yang bermaksud untuk memahami fenomena tentang 
apayang dialami oleh subjek penelitian misalnya perilaku, presepsi, motifasi tindakan dan lain-lai[8]. Secara holistic (utuh), dan dengan cara deskripsi dalam bentuk kata-kata dan bahasa pada suatu konteks kuhusus yang alamiah dan dengan memanaatkan berbagi metode alamiah[9].

Penelitian ini menggunakan metode kulitatif dengan pendekatan deskriptif yang bertujuan untuk mendapatkan data tentang pengaruh globalisasi terhabitandap nilai-nilai budaya pada rumah tradisional Masyarakat Dusun Sade Desa Rambitan Kecamatan Pujut.Yaitu berusaha menggambarkan fakta dan kenyataan sosial, kemudian dianalisis menggunakan pengetahuan dan konsep kebudayaanyang ada pada masyarakat Dusun Sade Desa Rambitan.

Ada beberapa pertimangan menggunakan kualitatif diantarannya[10] adalah sebagai berikut:

a. Menyesuaikan metode kualitatif lebih mudah apabila berhadapan dengan kenyataan langsung (jamak)

b. Metode ini menyajikan secara langsung hakikat hubungan antara peneliti dan responden

c. Metode ini lebih peka dan lebih dapat menyesuaikan diri dengan banyak penajaman pengaruh bersama terhadap pola-pola nilai yang dihadapi.

Dari beberapa pernyataan diatas maka dapat disimpulkan bahwa penelitian ini menggunakan penelitian kualitatif dengan menggunakan pendekatan deskriptif yaitu menjelaskan atau mendeskripsikan gejala atau fenomena yang telah dan sedang berlangsung.Adapun tujuan menggunakan metode penelitian kualitatif adalah untuk mendapatkan informasi tentang pengaruh globalisasi terhadap nilainilai budaya pada rumah tradisional masyarakat Dusun Sade.

\section{Lokasi Penelitian}

Lokasi Penelitian dilaksanakan di Dusun Sade Desa Rambitan Kecamatan Pujut Kabupaten Lombok Tengah.Kabupaten Lombok Tengah adalah salah satu provensi Nusa Tenggara Barat. Ibu kota daerah ini ialah kota prays. Kabupaten Lombok Tengah memiliki luas wilayah 1.208,39 km; dan populasi 745.433 jiwa.Kabupaten Lombok Tengah terletak pada posisi 82 7'-8 30' lintang selatan dan 116 10'- 116 30' Bujur Timur, membujur mulai dari kaki Gunung Rinjani di sebelah utara hingga ke pesisir pantai kuta di sebelah selatan, dengan beberapa pulau kecil yang disekitarnya.

3. Subyek penelitian

Informan penelitian dalam penelitian kualitatif tidak menggunakan populasi, karena penelitian kulitatif berangkat dari kasus tertentu yang ada pada situasi sosial tertentu dan hasil kajiannya tidak akan diberlakukan ke populasi, tetapi ditansferkan ke tempat lain pada situasi sosial yang memiliki kesamaan dengan kasus yang diteliti[11].
Penelitian kualitatif tidak menggunakan istilah populasi, tetapi menggunakan tehnik penentuan informan[12]. Informan adalah orang yang dimanfaatkan untuk memberikan informasi tentang kondisi latar penelitian, jadi ia harus mempunyai banyak pengalaman tentang latar penelitian[13]. Dalam penelitian ini, penentuan informan penelitian dilakukan dengan carapurposive sampling.

Purposive sampling adalah tehnik pengambilan sampel sumber data dengan pertimbangan tertentu[7]. Pertimbangan tertentu ini misalnya orang terebut yang dianggap paling tahu tentang apa yang diharapkan, atau mungkin ia sebagai penguasa sehingga akan memudahkan peneliti menjelajahi objek atau situasi sosial yang yang akan diteliti. Ia juga menjelaskan dua jenis penentuan informan yaitu[7]:

a.Informan kunci adalah orang yang dapat memberikan data atau informasi secara jelas.

b.Informan biasa adalah orang yang terlibat langsung dalam penelitian tersebut.

Berdasarkan penjelasan di atas maka dapat disimpulkan bahwa yang menjadi informan kunci dalam penelitian ini adalah masyarakat asli Dusun Sade, ketua adat dan pemerhatibudaya.Yang mengetahui tentang nilai-nilai budaya pada rumah masyarakat Dusun Sade Desa Rambitan Kecamatan Pujut Kabupaten Lombok Tengah.

4. Metode Pengumpulan Data

Teknik pengumpulan data dalam peneliti ini adalah melalui observasi, wawancara dan dokumentasi.

a. Observasi

Obsevasi adalah pengamatan dan pencatatan secara sistematik terhadap unsur-unsur yang tampak dalam suatu gejala atau gejala-gejala dalam penelitian.

Metode pengumpulan data dalam penelitian kulitatif secara umum dikelompokkan ke dalam sua jenis cara yaitu think yang besifat intraktif dan non aktif[12]. Metode ini meliputi interview dan observasi berperan serta, sedangkan metode nonintraktif meliputi observasi tidak berperan serta, tekhnik kuesioner, mencatat dokumen, dan partisipasi tidak berperan.

Secara garis besar observasi dapat dilakukan[14] dengan:

1. Partisipasi atau partisipan adalah peneliti merupakan bagian dari kelompok yang ditelitinya, minsalnya peneliti termasuk suku bangsa suku bangsa atau anggota perkumpulan dari apa yang diselidikinya.

2. Tanpa partisipasi atau non-partisipasi yaitu peneliti dapat mengadakan pengamatan denagn cara menyamar agar tidak disadari kehadirannya itu sebagai pengamat akan tetapi dapat juga ia melakukan pengamatan itu secara langsung

Dalam penelitian ini menggunakan teknik observasi non partisipasi, dimana peneliti akan melakukan pengamatan secara langsung dalam peroses pelaksanaan, peneliti hanyamencatat data-datayang dibutuhkansesuai denganfenomena yang sebenarnya tanpa adannya 
penambahandan pengurangan terhadap realitas yang tertjadi yaitupeneliti melakukan pengamatan hidup sosial masyarakat terutama yang berkaitan dengan nilinilai budaya pada rumah tradisional masyarakat. Dusun Sade desa rambitan kecamatan pujut kabupaten Lombok Tengah.

\section{b. Wawancara}

Dalam penelitian ini untuk mendapatkan informasi yang lebih mendalam tentang pengaruh globalisasi terhadap nili-nilai budaya pada rumah tradisional masyarakat Dusun Sade.

Wawancara adalah pertemuan dua orang untuk bertukar informasi dan ide melalui tanyajawab, sehingga dapat dikonstruksikan makna dalam suatu topik tetentu[7]. Wawancara digunakan sebagai teknik pengumpulan data apabila peneliti ingin melakukan setudi pendahuluan untuk menemukan permasalahan yang harus diteliti, tetapi juga apabila peneliti ingin mengetahui hal-hal dari responden yang lebih mendalam.

Selain itu wawancara atau interview terdiri dari beberapa jenis yaitu[7][15]:

1. Wawancara tersetruktur (structured interview) yaitu wawancara yang pertanyaannya-pertanyaannya telah disiapkan menggunakan pedoman wawancara

2. Wawancara semiterstruktur (semiterstruktur interview) yaitu wawancara sudah cukup mendalam karena ada penggabungan antar wawancara yang berpedoman pada pertanyaan pertanyaan yang telah disiapkan dan pertanyaan yang lebih luas mendalam dan mengabaikan pedoman yang sudah ada

3. Wawancara tak berstruktur (unstrukturred interview) yaitu wawancara yang bebas dimana peneliti tidak menggunakan pedoman wawancara yang telah disusun secara sistematis dan lengkap untuk mengumpulkan datanya. Pedoman yang digunakan hanya berupa garis besar permasalahan yang akan ditanyakan.

Wawancara yang digunakan dalam peneliti ini adalah wawancara, tidakbestruktur dimana wawancara bersifat luwes tanpa teks yang harus diikutiwawancara ini memakai kata-kata pertanyaan yang dapat dibuah saat wawancara, dengan penyesuaian kebutuahan dan situasi wawancara, dengan catatan tidak menyimpang dari informasi yang dibutuhkan untuk penelitian ini.

Adapun wawancara merupakan alat rechecking atau pembuktian terhadap informasi atau keterangan yang diperoleh sebelumnya[12]. Teknik wawancara yang digunakan dalam penelitian kualitatif adalah wawancara mendalam. Wawancara mwndalam (in-depth interview) adalah peroses memperoleh keterangan untuk tujuan penelitian dengan cara Tanya jawab sambil bertatap muka antara pewawancara denagn informan (guide) wawancara, dimana pewawancara dan informan terlibat dalam kehidupan sosial yang relatif lama.
Berdasarkan beberapa pendapat diatas dapat disimpulkan bahwa wawancara atau interview adalah merupakan pertemuan dua orang untuk bertukar informasi dan ide melalui tanyajawab sehingga dapat dikonstruksikan makna dari topik tersebut.

\section{c. Dokumentasi}

Dokumentasi merupakan teknik pengumpulan data yang ketiga yang dilakukan oleh peneliti untuk melengkapi data yang dibutuhkan untuk penelitian.Dokumen merupakan catatan peristiwa yang sudah berlalu.Dokumen bisa berbentuk tulisan (sejarah kehidupan, cerita) gambar (foto, sketsa) atau karyakarya monumental dari seseorang.

Studi dokumentasi merupakan pelengkap dari penggunan metode observasi dan wawancara dalam peneliti kualitatif. Bahkan kredibilitas hasil penelitian kualitatif ini akan semakin tinggi jika melibatkan /mengunakn studi dokumen ini dalam metode penelitian kulitatif[8].

Ada beberapa keuntungan dari penggunaan studi dokumen dalam penelitian kulitatif[14],

1) Bahan documenter itu telah ada, telah tersedia, dan siap paki,

2) Penggunaan bahan ini tidak meminta biaya, hanya memerlukan waktu untuk mempelajarinya,

3) Banyak yang dapat ditimba pengetahuan dari bahan itu bila dianalisis dengan cermat, yang berguna bagi peneliti yang dijalankan.

4) Dapat memberikan latar belakang, yang lebih luas mengenai pokok penelitian

5) Dapat dijadikan bahan triagulasi untuk mengecek keseuaian data

6) Merupakan bahan utama dalam historis.

Berdasarkan teori diatas dapat disimpulkan bahwa dalam teknik dokumentasi ini peneliti akan mengunakan foto atau dan catatan tentang penagruh gelobalisasi dalam nilai-nilai budaya.

5. Jenis dan Sumber Data

Dalam jenis penelitian, peneliti memerlukan data yang akurat agar hasil kajian dapat dipertangung jawabkan kebenaranya. Dalam melaksanakan penelitian ada dua jenis data, yaitu data kualitatif dan kuantitatif.

a) Data kuantitatif data yang berupa angka dengan melalui penelitian perhitungan

b) Data kulitatif adalah data-data yang berupa uraian dengan melalui uraian penelitian kehidupan sosial

Dari beberapa pendapat diatas dapat disimpulkan bahwa data yang digunakan dalam penelitian ini adalah jenis data kualitatif, yang dengan cara menjelaskan secara sistematis, analisis dan logis dari permasalahan.

Ada dua sumber data[7] yaitu:

(1) Sumber data perimer adalah sumber data yang langsung memberikan data kepada pengumpulan data. 
(2) Sumber data sekunder adalah sumber yang tidak langsung memberikan data kepada pengumpul data, minsalnya lewat dokumen atau orang lain/perantara

Sumber utama dalam penelitian kulitatif ialah katakata, dan tindakan secara langsung. Selebihnya adalah data tambahan atau sekunder seperti dokumen dan lainlain[16].

Berdasarkan beberapa teori di atas yang menjadi data perimer hasil pengumpulan data melalui obserfasi dan wawancarta sedangkan yang menjadi data sekunder adalah dokumen-dokumen yang berhubungan dengan rumah tradisional pada masyarakat Sasak.

6. Metode Analisis Data

Aktivitas dalam analisis data kualitatif dilakukan secara intraktif dan berlangsung secara terus menerus sampai tuntas sehingga datanya sudah jenuh. Reduksi data, penyajian data, dan menarik kesimpulan[17].

a. Reduksi data

Mereduksi data berarti merangkum data, memilih hal-hal yang pokok, memfokuskan hal-hal yang penting, dicari tema dan polanya. Dengan demikian data yang telah direduksi akan memberikan gambaran yang lebih jelas dan mempermudah penelitian untuk melakukan pengumpulan data selanjutnya dan mencarinya bila diperlukan setelah melakukan reduksi data yang diangap sudah falid, maka dilakukan selanjutnya yaitu penyajian data (data display).

b. Penyajian data

Setelah data direduksi, maka selanjutnya adalah mendisply data.Dalam penelitian kualitatif, penyajian data dapat dilakukan dalam bentuk uraian singkat, bagan dah hubungan antara kategori.

Langkah ke tiga dalam analisis data kulitatif adalah penarikan kesimpulan dan verifikas. Kesimpulan awal yang dikemukakan masih bersifat seementara, dan akan berubah bila tidak ditemukan bukti-bukti yang kuat yang mendukung pada tahap pengumpulan data berikutnya tetapi apabila kesimpulan yang dikemukakan pada tahap awal didukung oleh bukti-bukti yang valid dan konsisten saat peneliti ke lapangan mengumpul data, maka kesimpulan yang dikemukakan merupakan kesimpulan yang keredibel.

\section{c. Menarik Kesimpulan}

Menarik kesimpulan atau vertifikasi data dalam rangka memuat kesimpulan hasil penelitian yang dituang dalam pembahasan.Setelah data direduksi dan disajikan maka dilakukan kesimpulan tentang pengembangan pengaruh globalisasi terhadap nilai-nilai budaya pada rumah tradisional masyarakat Dusun Sade desa rambitan kecamatan pujut kabupaten Lombok Tengah.

\section{HASIL DAN PEMBAHASAN}

\section{Pengaruh Globlisasi Terhadap Nilai-Nilai Budaya Pade Rumah Sade}

Globlisasi benyebabkan banyak pengaruh terhadap nilai-nilai budaya kususnya pada rumah taradisional masyarakt Sade, berdasarakan hasil observasi yang dilkukan dilapangan terdapat beberapa pengaruh globalisasi terhadap nilai-nilai budaya masyarakat diantaranya

a. Nilai Estetika yang merupakan nilai keindahan, yang dimana banyak hal yang berhubungan dengan nilai Estetika seperti keidahan yang ada pada rumah teradiasional suku sasak yang ada pada masyarakat Dusu Sade, yang masih telhiat sampai saat ini namun dengan perkembangan zaman dan globalisasi menyebabkan masyrakat sudah mulai menggunakan banggunan moderen.

b. Nilai kearifan lokal yang merupakan suatu teradisi yang telah diwarisi oleh nenek moyang, bahawa kebiasaan masyarakat Sade menggunakan bahan banggunan dari alam seperti atap menggunakan alang-alang, dinding dari anyaman bambu dan lantai menggunakan kotoran kerbau yang dicampur dengan tanah liat, namun saat ini masyrakat Sade bnyak yang sudah menggunakan semen sebagi lantainya.

c. Nilai Memperekat lantai (belulut) menggunkan kotoran kerbau, hal ini juga salah satu teradisi yang sudah diwarisi oleh nenek moyang masyarakat Sade, namun dengan perkembangan zaman dan globalisasi, membuat masyarakat jarang menggunakan kotoran kerbau untuk belulut lantai.

Hal di atas diperkuat dengan hasil wawancara Wira Darje dengan masyrakat Sade yang berjumlah tiga orang diperoleh hasil wawancara masayarakat biasa yang dimana selaku mengatakan bahwa:

Dampak atau pengaruh globalisasi pada nilainilai budaya pada rumah tradisional kami semakin hari semikn Nampak. Terlihat dari bnyaknya msyarakat kami yang menggunakan semen untuk membuat lantai dari 150 rumah hanya tersisa 35 yang masih menggunakan tanah lia dan dicampur dengan kotoran kerbau untuk membuat lantai rumah dan selin itu sudah menggunakan semen, bukan hanya semen saja tetapi banyak diantara masyrakat Sade sudah menggunkan kaca tidak menggunkan kayu, tetapi msyarakat Sade satu semuanya masih menggunakan kotoran kerbau untuk mengepel lantai baik yang menggunkan semen maupun kotoran kerbau. (wawancara pada tanggal 24 April 2018) 
Menurut Inaq Ruminah salah satu pemilik rumah Sade yang sudah menggunkan semen sebagi latainya beliau mengtakan bahwa:

Saya menggunkan semen pada lantai, karana saya sudah bosen menggunkan tanah lihat sebagi latai rumah saya dan banyak masyarakat Sade yang lain yang menggunkan semen seperti saya sebagi lantai kami, tetapi, kami tidak menghilankan nilai-nilai budaya kami yang menggunakan kotoran kerbau untuk mengepel lantai. Kami masih mengepel lantai dengan kotoran kerbau. (Wawancara pada tanggal 24 April 2018)

Dari uraian di atas dapat ditari kesimpulan bahwa globalisasi telah mempenagruhi banyak hal terhadap nilai nilai budaya khususnya pada rumah teradisional masyrakat Sade. Terlihat dari bnyaknya banguna yang sudah mulai menggunakan bngunan moderen hal ini justru akan membuat nilai estetika, nilai keindahan akan memudah karena keaslian dari pada rumah itu sediri sangat penting karana salah satu bentuk warisan dari nenek moyang, begitu pula dengan belulut atau yang dikenal dengan pemperkuat tanah dengan menggunkan kotoran kerbau yang sudah jarang dilakukan oleh masyarakat setempat.

Hasil wawancara dengan Inaq Nawi dan Amaq Nawi salah satu pemilik rumah masyarakat Sade yang masih mempertahankan lantai rumah mereka dengan lanti terbuat dari tanah liat dan kotoran kerbau. Beliau mengatakan bahwa:

Saya salah satu dari sekian banyak masyarakat Sade yang masih memperthankan keaslian rumah kami dengan menggunakan tanah liat denagn campuran kotoran kerbau. Sebagi lantai rumah kami bnyak dari mereka yang sudah menggunkan semen.Dan dari setruktur rumah kami tidak ada yang menggunkan bahan bagunan yang seperti zaman sekrang tetapi saya menggunakan semua bahan banggunan dari alam seperti bambu, kayu, alang-alang sebagi atap rumah kami.Dan masih memegan nilai-nilai budaya, yang masih mengepel lantai menggunkan kotoran kerbau.Mengepel lantai dengan kototran kerbau dilakukan dalam jangka waktu satu kali dalam dua minggu. Keggunaan supaya lantai terhindar dari nyamuk, dan lantai tidak mudah retak. (Wawancara pada tanggal 25 April 2018)

Sade atau dusun Sade terbagi menjadi tiga bentuk yaitu, Sade satu, Sade dua, dan Sade tiga namun hanya Sade satu yang masih mempertahankan teradisi masyarakat, yang menggunakan rumah sasak tempo dulu.Yang jika diperhatikan dibnagunan berdasarkan nilai estetika dan kerarifan lokal.Orang sasak mengenal beberapa jenis bangunan adat yang menjadi tempat tingal dan juga tempat ritual dan ritual keagamaan.
Berdasarkan hasil wawancara dengan amaq rusdi.salah satu masyarakat asli suku sasak di dusun Sade.Dan sekaligus sebagi pemandu wisata menjelaskan:

Sade terbagi menjadi beberapa.ada Sade satu, Sade dua, dan Sade tiga. Namun yang masih mempertahankan teradisi masyarakat lokal hanyalah Sade satu. Sade dua dan Sade tiga telah menggunakan bangunan moderen seperti genteng, sebagai atap rumah, kaca dan mengunakan keramik sebagi lati dalam rumah itu.Perkembangan kemajuan zaman dan arus globalisasi telah membuat masyarakat Sade mengunakan rumah moderen seperti yang ada di luar Sade. Karena sudah mulai bosan mengunakan rumah sasak tempo dulu. Masyarakat Sade dua dan Sade tiga tidak hanya mengandalkan pekerjaan dari pertanian dan pariwisata namun kebnyakan dari mereka juga pergi merantau di luar negri. Sebagai TKI. Dan hanyalah Sade satu yang mengandalkan pendapatan atau penghasilan masyarakatnya melalui pertanian dan pariwista. (Wawancara pada tanggal 25 April 2018)

Dari penuturan yang diungkapkan oleh amaq rusdi.selaku masyarakat asli suku sasak yang di dusun Sade, dan sekaligus sebagai pemandu wisata tentang dusun Sade.

Amaq safi juga menyatakan bahwa :

Sade sekarang tidak seperti Sade yang dulu, dusun Sade yang dulu baik Sade satu, Sade, dan Sade tiga masih menggunakan rumah sasak tempo dulu, yang masih memegan nili-nilai estetika dengan kearifan lokal masyarakat asli suku sasask.dan mempunyai filosofi, makna tersendiri di setiap ruangan yang ada di dalam rumah suku sasak, namun sekaran sudah berubah karna kemajuan arus modenisasi yang sangat pesat. Hanya Sade satu yang masih menggunakan rumah sasak tempo dulu, yang rumah adat adat suku sasak terbuat dari jerami dan berdinding dari anyaman bambu (bedek).Lantai dari tanah liat yang dicampur dengan kotoran kerbau dan abu jerami.Campuran tanah liat dan kotoran kerbau membuat lantai tanah mengeras, sekeras semen.Cara membuat lantai seperti itu sudah diarisi sejak nenek moyang mereka. (wawancara pada tanggal 25 April 2018)

Begitu juga hasil wawancara dengan Kepala Dusun Sade Kurdap Selake S.Pd beliau mennyatakan bahwa: Perkembangan arus globalisasi terhdap nilainilai budya sudah mulai terpengaruh, kalu dilihat dari struktur rumah msyarakat Sade, pertama dilihat dari segi material yang dimana masyarakat sudah mulai menggunkan batu 
bata, semen dan juga kayu pun menggunkan kayu inpor dari daerah lain karana kayu di daerah Sade sudah mulai langka. Namun masyarakt dusun sdae sebagian besarnya masih memegan teradisi mengepel lantai menggunkan kotoran kerbau hal ini masih dipertahankan hingga sekaran karna masyarakat percaya belulut atau menggepel lanti menggunkan kotoran kerbau dipercya dapat meperekat dan memperkuat lantai rumah.(wawancara pada tanggal 25 April 2018)

Dari hasi wawancara diatas dapat disimpulkan globalisasi nyatanya sudah meberikan pengaruh dan dampak yang sangat besar tehadap nilai-nilai budaya pada masyarakat Sade. Terlihat dari struktur banggunan masyarakt yang sudah banyak berubah mulai dari lantai kaca dan bahka pola kehidupan sosial masyarakat pun sudah mulai berubah terlhitat dari pakaian msyarakat dan pola-pola kehedupan yang lain seperti tutur bahasa yang sudah mulai tidak menggunakan bahasa adat suku sasak yaitu bahasa halus. Seperti tiang, niki, sampun, dan lain-lain.Dusun Sade Juga sebagi salah satu objek wisata yang terkenal dengan rumah sasak tempo dulu yang masih berdiri kokoh dengan mengandung nilainilai estentika.Namun akibat dari kemajuan zaman yang semakin pesat, mbuat masyaraktnya mulai membuat rumah denagn bergaya modern. Hal ini terlihat dari Sade dua dan Sade tiga tidak mengunakan rumah sasak tempo dulu, yang mengandung nilai estentika seperti Sade satu

\section{Nilai-Nilai Budaya pada Rumah Sade}

Nilai budaya merupakan suatu nilai yang sudah ada dalam kehidupan masyarakat dan yang berguna bagi kehidupan manusia. Nilai budya yang ada pada Rumah Dusun Sade sebagi berikut:

a. Nilai religi, rumah Sade juga memiliki nilai religi terlihat dari pembuatan rumah yang harus ada sukurannya. Penetapan tangal dan hari pembuatan rumah ditentukan oleh masyarakat yang paling tua dan kepala Dusun Sade.

b. Nilai gotong royong, nilai gotong royong sangat dipengang teguh oleh masyarakat Sade terlihat dari ketika pembuatan rumah masyrakat Dusun Sade, sehingga dalam pembuatan rumah Sadetidak membutuhkan watu yang cukup lama namun dalam watu satu bulan pun masyarakat dusun Sade sudah mulai menepatinya karna dilakukan secara besama-sama dan tampa imbalan (upah).

c. Nilai etika yang dijadikan pedoman bagi anggota masyarakat bagimana cara bertingkah laku. Yang dimana pada rumah Sade mengandung nilai etika yang sangat kuat, terlihat dari bentuk bangunan yang memiliki makna seperti ketika mmemasuki rumah Dusun Sade harus merunduk dan mengucap salam kepada pemilik rumah. d. Nilai etetika yang merupakan nilai keindahan, yang dimana banyak hal yang berhubungan dengan nilai Estetika seperti keidahan yang ada pada rumah teradiasional suku sasak yang ada pada masyarakat Dusu Sade, yang masih telhiat sampai saat ini namun dengan perkembangan zaman dan globalisasi menyebabkan masyrakat sudah mulai menggunakan banggunan moderen.

Dari hasil wawancara dengan Kurdap Selake S.pd kepala Dusun Sade.

Budaya gotong royong kami sangat terapkan dan masih menjaganya hingga saat ini, karna saat ini budaya gotong royong sudah mulai hilang di tempat lain, namun budaya gotong royong masih ada di masyarakat Sade. Karna masyarakat Sade sudah memegang teguh ikatan persaudaraaan, begitu juga denagn nilai etika yang ketika bertamu harus tunduk sediki, member salam kepda pemilik rumah. Yang masih dipertahankan oleh masyarakat. Dan globalisasi juga sangat memberikan penagruh terhadap pola perilaku masyarakat Sade yang dimana seperti menggunakan pakaian yang sudah moderen (wawancara 30 april 2018)

Dari uraian di atas dapat disimpulkan nilai-nilai budaya yang ada pada masyrakat seperti nilai religi, nilai kearifan loka, niali etika dan nilai gotong royong masih ada pada rumah teradisiol masyarakat Dusun Sade hanya saja ada beberpa yang masih menggunakan nilai kearifan lokal, terlihat dari sebagian masyarakat sudah banyak menggunakan yang moderen. Namun yang masih tidak dapat terpenagruh oleh globalisasi yaitu nilai gotong royong yang masih ingga saat ini masih ada pada masyarakat Dusun Sade.

\section{Bentuk Bangunan Dusun Sade}

Bangunan di Dusun Sade memiliki ciri khas dari bangunan suku sasak yang sangat tradisional, diding yang berbahan anyaman bambu (bedek), tiang dan paku terbuat dari kayu bambu dengan atap dari daun alang-alang kering.Lantai yang terbuat dari tanah liat dicampur dengan abu jerami dan kotoran kerbau. Campuran ini menjadikan lantai tanah mengeras, sekeras semen.Bahkan, untuk membersihkan lantai pun penduduk masih menggunakan kotoran kerbau yang dicampur dengan sedikit air dalam jangka waktu seminggu sekali, setelah kering kemudian disapu dan digosok dengan batu.Cara ini dimaksudkan untuk membersihkan lanti dari debu, memperkuat lantai, dan menutupi retakanretakan yang timbul. Namun saat masuk kedalam rumah, tidak akan tercium bau busuk dari kotoran sapi atau kerbau. Jarak dari bangunan satu ke bangunan yang lainnya sangat rapat dan hanya dihubungkan dengan jarak setapak yang tidak bisa dilewati kendaraan bermotor pintu disetiap rumah 
memiliki bentuk yang sama, tetapi terdapat perbedaan menurut penggunaannya:

\section{a. Bale Gunung Rate/Tani}

Bale gunung rate / tani sebagai tempat tinggal penduduk yang bermata pencahrian sebagai petani. Dan sebagi tempat menaruh padi biasanya juga dikenal dengan sebutan lumbung padi.Bale ini berbentuk limas an atau joglo.Terdiri dari dua ruangan, yaitu bale dalam dan bale luar.Sedangkan Bale dalam atau ruangan dalam digunakan untuk tempat tidur anak gadis dan merangkap sebagi dapur. Terdiri dari dua tungku yang menyatu dengan lantai. Biasanya, penduduk menggunakan kayu sebagi bahan bakar, karana penduduk tidak menggunakan minyak tanah, gas dan lain-lain Untuk memasak. Hanya menggunakan kayu bakar dan sebagian besar juga penduduk masih bermata pencaharian sebagi petani. Ruangan ini tidak memiliki jendela dan hanya satu pintu untuk keluar dan masuk ruangan ini tertutup rapat hingga gelap gulita, dimksdkan agar anak gadis tidak mudah diculik.Bale luar (sesangkok) sesangkok dalam arti bale luar, sesangkok menjadi tempat tidur anggota keluarga lainnya dan berfungsi sebagi raungan tamu. Antara kedua bale ini, dipisahkan denagn pintu geser dan tiga buah anak tangga.

\section{b. Bale Bonter}

Bale Bonter, dimiliki oleh pejabat desa. Biasanya, dibangun ditengah-tengah pemukiman.Bele ini diggunakan untuk tempat persidangan adat seperti tempat penyelesaian masalah pelanggaran hukum adat dan sebagainya.Bale bonter juga disebut gendang pengukuhan dan tempat penyimpanan benda-benda bersejarah atau pusaka warisan keluarga.

Hal di atas, diperkuat dengan pernyatan dari tokoh masayarakat dusu Sade suku sasak .dari hasi wawancara dengan amaq ari beliu menyatakan:

Bentuk bangunan dusun Sade yang bisanya dikenal dengan bale tani, bele jajar dan bale bonter. Namu yang paling umum adalh bale tani. Knpa di sebut bale tani karna semunya masyarakat suku sasak khususnya yang ada di dusun Sade masyarakatnya bertani, seningga disebutlah sebgi bale tani.Bale tani memiliki beberapa ruangan sebut bale dalam, bale luar (sesangkok) bale jajar dan bale bonter. Bale dalam digunkan sebagi tempat tidur, bale luar digunakan sebagi tempat menerima tamu, bale bonter digunakan sebagi tempat persidangan adat dan pertemuan kerabat (wawancara pada tanggal 30 april 2018)

Pendapat Amaq Ari diatas di perkuat lagi oleh Inaq Ruli bagimana bentuk bangunan dusun Sade Inaq menagtakan :

Bangunan dusun Sade sangat kental dengan bangunan sasak tempo dulu yang dikenl denagn sebutan bale tani, bale tani memiliki ruangan, bale dalam bale lauar bale bonter. Dan memiliki keggunaa dan fungsinya dalam bale tani juga didalamnya ada tiga buah tanga. Tangga ini berguna untuk menguhubungkan bale luar dan bale dalam. Karna posisi bale luar (sesangkok) denagn bale dalam posisinya aggak atas. Tembok dari bale tani terbuat dari anyaman bambu dan didalam bale laur (sesangkok) terdiri dari empat ting penyangga yang terbuat dari pohon bambu didalam bale tani terdapat pula satu ruangan yang disebut dengan sebutan pawon (dapur) yaitu tempat memasak bagi masyarakat suku sasak. Di dusun Sade. (Wawancara pada tanggal 30 april 2018)

Bangunan dusun Sade sangat alami dan masih memperthankan rumah adat susuk sasak tempo dulu yang memiliki struktur bngun yang dimana disebut dengan bale tani. Bale tani terdapat beberapa ruangan yang disebut sebagi bale dalam, bale luar, bale jajar dan bale bonter yang memiliki keggunaan dan fungsi masing-masing. Sehingga dusun Sade ini sebagi obyek wisata yng ada di Lombok tengah , NTB karna keaslian bangunan rumah penduduk masyarakt suku sasak yang ada di dusun Sade.

\section{Filosofi Bangunan Bangunan Rumah Sade}

Filosofi yang terkandung dalam bangunan dusun Sade yaitu nilai estentika (nilai keindahan) kearifan lokal masyarakat. Dalam setiap ruangan, bentuk bangunan, bahan bangunan dan arahnya memiliki makna dan filosofi tersendiri.Bentuk bangunan yang atapnya menjulang tinggi seperti gunung renjani.Mengaku bahwa tuhan yang maha esa dan palinggtingi dari segala mahluk yang ada di muka bumi.itulah makna yang terkandung dalam atap ruamh yang menjulang tinggi.Secara lebih terperinci penulis mencoba memaprkan beberapa nilai dan filosofi yang terkandung dalam bangunan dusaun Sade :

Atap alang-alang akan member rasa sejuk saat cuaca terik, dan sebaliknya akan memberikan rasa hngat di malam hari. Alang-alang juga bnyak di jumpi di sekitar sawah masyarakat dusun Sade, Membersikah lantana menggunakan kotoran kerbau. Masyarakat dusun Sade mempercayai dapat membuat rumah mereka hangat, terhindar dari serangga dan konon dapat menangkal serang mangis dan mistis yang ditunjukkan bagi penghuni rumah. Sedangkan Pintu rumah dibangun tidak melebihi tinggi orang dewasa, pintu rumh juga tidak seperti pintu rumah pada umumnya pintu rumah Sade di buat bolong tengahnya. Dimaksudkan agar setiap tamu yang dating harus merunduk sebagai tanda penghormatan kepada tuan rumah.Tiga buah anak tangga yang memishkan antar bale menandakan Wetu Telu, yaitu dulu masyarakat Sade memegang kepercayaan animisme yang pada saat itu berkembang agama hidu, dan juga dulu klu ingin sholat biasanya juga diwakili oleh tuan guru (ustad). Selain itu juga sebagi lambang kelahiran, berkembang dan mati serta sebagi lambing keluarga yaitu ayah ibu dan anak. 
Penggunaan rumah dengan arah dan ukuran yang sama menunjukan bahwa masyarakt hidup harmonis. Oleh karna itu, jika ada yang membangun rumah yang sudah ada, maka itu mennandkan bahwa penghuni dusun tersebut tidak harmonis..Sedangkan Empat tiang pennyangga berugakq mempunyai pengertian atau makna kebenaran yang harus diutamakan, kepercayaan dari dalam memegang amanah, dalam menyampikan sesuatu hendaknya berlaku jujur dan polos, dan sebagi orang yang beriman hendaknya pandai/cerdas dalam menyikapi masalah (tanggap). Sedangkan atapnya menggambarkan keyakinan bahwa tuhan maha tahu atas segalanya, baik yang tersirat maupun yang tersurat.

Ada juga yang beranggapan bahwa pesan dari berugaq bertiang empat adalah symbol syariat islam: Quran, Hadis, Ijma, Qiyas. Disamping itu, berugak yang ada di depan rumah merupakan bentuk rasa syukur terhadap rezeki yang diberikan tuhan, dan juga sebagai tempat berintraksi dengan masyarakat lainnya.Keberadaan lumbung padi menunjukkan bahwa warga sasak harus hidup hemat dan tidak boros bahan-bahan yang disimpan di dlamnya, hanya bisa diambil pada waktu tertentu, minsylnya sekli sebulan sebagi persiapan untuk keperluan mendadak, minsyalnya karena panen gagal atau karena ada salah satu anggota keluarga meninggal.

Hal diatas diperkuat oleh pernyataan dari tokoh masyarakat yang ada di dusun Sade, dari hasil wawancara dengan Wira Darje. Beliau menyatakan:

Bahwa bale tani memiliki filosofi di dalam setiap bangunan yang ada dalam bale tani yang dimana sangat kental filosofinya dan maknanya, yaitu pintu mengambarkan bahwa kita harus merunduk, dan saling menghargai satu dengan yang lainnya. Dan didalam bale tani terdpat tiga buah tanga, tangga ini mengambarkan islam waktu telu, antara islam hidu dan animism yang dimana masyarakat dulu memegang tiga kepercayaan. Masyarakat Sade dulu sholat, jumtan diwakilkan dengn seorang kiyai, tapi sekrang tidak, itu berlaku hanya zaman dahulu sajak. Dan sekrang sudah mengenal lima waktu oleh krna itu sekrang tnggnya ditmbah dua menjadi lima buah anank tangga dan itu menandakan bahwa msyarakat Sade sudah mengerjakan soholat dengan lima waktu. (Wawancara pada tanggal 30 April 2018)

Pendapat Wira Deraje di atas diperkuat oleh Dedare Aton bagaiman nilai-nilai dan filosofi yang terkandung dalam rumah bale tani. Beliau mengatakan mengatakn bahwa:

Bale tani juga disebut bale gunung rata. Diaktakan demikin karna diatasnya seperti gunung dan depan rate supaya air hujan turun kebawah dan tidak mengenagi teras depan tau ble luar dan seperti gunung mengambarkan keyakinan bahwa tuhan maha tau segalanya, dan tuhan maha tinggi sehingga sampi detik ini kami masih memperthankan rumah Sade yang mengandung nilai dan filosofinya tersendiri. Jika dilihat dari sejrahnya sekarang rumah Sade sudah memasuki enam belah generasi.

(wawancara pada tanggal 30 April 2018)

Dari pernyataan di atas dapat disimpulkan nilainilai dan filosofi yang ada pada rumah tradisional masyarakat dusun Sade sangt kental dengan kehidupan masyarakt suku sasak tempo dulu.Yang masih memegang teguh nilai-nilai kemanusiaan, seperti pintu, pintu mengambarkan bahwa kita harus saling menghoramti antar masyarakat, umat beragama dan pemilik rumah yang dimana pintu dibuat harus merudunduk.dan masaih menunjukan nilai-nilai gotong royong yang diman jika membuat rumah masih gotong royong.

\section{Unsur Pembentuk Ruangan}

Ruangan tidak dapat dipisahkan dari kehidupan manusia, baik secara pisikologi emosional dan dimensional.Manusia berada dalam ruang, bergerak, menghayati, berfikir dan juga menciptakan bentuk dinianya. Dan juga rungan sangat di perlukan di dalam rumah, yang dimana rumah masyarakt Sade memiliki kegunan dan filosofi tersendriri dibalik ruangngan itu sendiri. Secara umum rungan dibentuk oleh tiga pembentuk elemen ruangan yaitu:Bidang Alas/lantai lantai merupakan pendukung segala aktifitas kita didalam ruangan. Lantai rumah yang terbuat dari campuran tanah, getah pohon, dan abu kemudian dioleskan denagn kotoran kerbau.Menurut warga Sade, kotoran kerbau berfungsi sebagi penghilang kelembaban tanah dan juga berfungsi pengusir nyamuk.Warga dusun Sade punya kebisaan unik yang sampi saat ini masih dipertahankan yaitu mengepel lantai menggunakan kotoran kerbau setiap dua minggu sekali. Jaman dahulu ketika belum ada pelester semen, orang sasak Sade mengolesakn kotoran kerbau di alas rumah hanya bercampuran dengan air saja.

Sedangkan Bidang Dinding/pembatas bidang dinding dapat menyatu dengan bidang lantai atau sebagi bidang yang terpisah.Dinding-dinding terbuat dari anyaman bambu (bedek).Bahan bangguan seperti kayu dan bambu didapatakn dari bambu.Didalam pengguanaan bambu sebagi dinding rumah memiliki filosofi tersendiri yang masih menjaga keaslian rumah tempo dulu yang masih kental dengan nilai-nilai budaya.Begitu juga Bidang atap, bidang atap adalah unsur pelindung utama dari suatu bangunan dan pelindung terhadap pengaruh iklim. Atap rumah tradisional sasak didisain sangat rendah denagn pintu berukuran kecil, bertujuan agar tamu yang dating harus merunduk sikap merunduk menandakan sikap saling hormat menghoramti dan saling menghargai antara tamu denagn tuan rumah. Atap bumbungannya dibuat dari jerami atau alang-alang dan juag rumbian.Budaya gotong royong masih tetap mereka lestarikan hingga saat ini. Budya gotong 
royong mereka tersebut tampak pada saat rumh salah seorang warga mengalami kerusakan, para tetangga secara sukarela ikut membantu memperbaikinya dari menganyam alang-alang hingga menaikkan atap dan mengganti diding, mereka melakukan semua itu besama-sama secra gotong royong dan sukarela tampa mengharapkan imbalan .

Hal di atas diperkuat oleh pernyataan dari tokoh masyarakat Sade.dari hasil wawancara denagn Amaq Giok, beliu menyatakan bahwa:

Masyarakat dusun Sade masih menggunakan adat dan teradisi, zaman dahulu seperti masih mengepel lanti dengan kotoran kerbau.Masyarakat Sade juga masih memegang budaya gotong royong dalam membuat rumah, serta masih menggunakan musyawarah mupakat dalam menyelesikan masalah yang diserah kepada kepala dusun. (wawancara pada tanggal 1 meil 2018).

Sependapat dengan amaq Giok Inaq Ruli juga memberikan pendapatnya tentang tradisi yang ada pada masyarakat dusun Sade. Beliau menyatakan bahwa:

Tradisi yang ada pada masyarakat Sade sampi saat ini masi di pertahankan, karena tradisi sebagi bentuk warisian dari nenek moyang kami, teradisi mengepel lantai dengan kotoran kerbau sudah menjadi kebiasaan masyarakat Sade, yang turuntemurun kepada sekelompok masyarakat berdasarkan nilai budaya masyarakat, bertingkah laku baik dalam kehidupan yang besifat duniawi maupun hal-hal yang bersifat gaib di dalam tradisi diatur bagimana manusia berhubungan dengan manusia lain atau sekelompok manusia lainnya, bagimana manusia bertindak terhadap lingkungan dan bagimanana perilaku manusia terhdap alam yang berkembang menjadi suau sistem memiliki pola norma yang sekligus juga mengatur penggunaan sanksi dan ancaman. (wawancara pada tanggal 1 meil 2018).

Tradsisi adalah suatu warisan dari nenek moyang kita, dan harus dijaga dilestrikian supaya tidak hilang oleh perkembangan zaman. Teradisai juga mengatur kita bagimana cara kita bertingkah laku dengan sekelompok manusia lain berdasarkan nili-nilai budaya yang ada pada msyarakat. Yang dimana dalam teradisi mengandung nilai-nilai kehidupan yang harus dipertahankan sehinga anak cucu kita masih melihat teradisi tersebut.

\section{SIMPULAN DAN SARAN}

Gobalsisasi memberikan dampak yang sangat besar, terhadap nilai-nilai budaya pada rumah tradisional masyarakat dusun Sade desa rambitan kecmatan pujut kabupaten Lombok tengan. Dusun Sade slah satu dusun yang sangat terkenal karna dusun Sade inilah yang masih memperthankan leaslian rumah teradisional suku sasak yang sangat terkenal dengan nilai-nilai budayanya. Namun dengan adanya globalisasi yang semakin pesat membuat masyarakat Sade sudah terpengaruh oleh globalisasi, terlihat dari lantai rumah yang sudah banyak masyratnya memaki semen sebagi lantai bahkan ada yang memaki keramik sebagi lantainya. Dan ada juga masyarakatnya yang memiliki kaca.

Dusun Sade terkenal dengan teradisi mengepel lantai menggunkan kotoran kerbau yang telah diwarisi secara turun temurun yang memiliki nilai-nilai tersendiri dan harus diperthankan supaya tidak tersingkirkan oleh perkembangan zaman yang semakin hari semkin pesat.

Pola kehidupan masyarakt Sade yang sampi saat ini masih mempertahankan budaya gotong royong dalam membuat rumah, rumah masyrakat dibuat dalam jangka waktu satu bulan dengan dilakukan secara besmam sama tampa menghrapkan upah atau imblan dari pemilik rumah namun masyrakt Sade membantu masyrakat yang membuat rumah dengan suka relah.

Arah dan ukuran rumah masyrakat dusun sangat terlihan unik dimana arah rumah yang memilik nilai budaya. Arah rumah harus saling berhadapan antara rumah yang satu denagn rumah yang lain hal ini menandakan bahwa pemilik rumah yang satu dengan pemilik rumah yang lain hidup harmonis dan saling berdampingan. Ukuran rumah yang sama rata dengan ukuran yang sama besar menandakan rumah masyrakat tidak ada yang lebih kaya dan tidak ada yang lebih miskin menandkan kehidupan sosial masyarakat sama rata. Hannya saja banyak dari masyrakat yang menggunkan semen sebagi lantai dikarnakan masyarakat Sade sudah mulai bosan menggunkan tanah lihat sebagi lantai mereka.

Dengan demikian disarankan bahwa Rumah tradisonal masyarakat dusun Sade harus perlu kita lestraikan karna rumah masyarkat dusun Sadeadalah cerminan rumah msyarakat suku sasak tempo dulu yang masih memperthankan nilai-nilai budaya dengan nilai estentika denagn kearifan lokal masyrakat. Jangan kita biarkan dengan kemajuan zaman yang semakin pesat membuat bentuk keaslian rumah akan tergeser dan lamat laun akan menghilang.

Pemerintah harus menjaga bentuk keaslian rumah dan jangan ada yang dirubah, karna dengan bentuk arsitektur rumah yang sanagat unuk yang di setiap ruangan memiliki nilai dan filosofinya seperti arah rumah, bentuk bangunan yang menjulang tinggi ketas dan yang paling terkenal adalah mengepel lantai menggunkan kotoran sapi atau kerbau. Hal seperti ini yang ahrus dilestarikan oleh masyarata suku sadsak, memerintah, dan para pemerhati budaya jangan biarkan perkembamgan teknologi globalisasi dan perkembangan zaman membuat keaslian rumah dan nilai-nilai budaya akan tersingkirkan.

\section{UCAPAN TERIMA KASIH}

Penulis mengucapkan terima kasih kepada pihak Universitas Muhammadiyah Mataram yang senantiasa memberikan saran, masukan, dan dana kepada penulis sehingga artikel ilimiah ini selesai dengan baik. 


\section{DAFTAR RUJUKAN}

[1] D. Budimansyah, "Tantangan globalisasi terhadap pembinaan wawasan kebangsaan dan cinta tanah air di sekolah," J. Penelit. Pendidik., vol. 11, no. 1, pp. 8-16, 2010.

[2] S. Suneki, "Dampak globalisasi terhadap eksistensi budaya daerah," CIVIS, vol. 2, no. 1/Januari, 2012.

[3] N. P. Suwardani, "Pewarisan nilai-nilai kearifan lokal untuk memproteksi masyarakat Bali dari dampak negatif globalisasi,” $J$. Kaji. Bali (Journal Bali Stud., vol. 5, no. 2, 2015.

[4] S. Soemardjan and S. Soemardi, Setangkai Bunga Sosiologi. Jajasan Badan Penerbit Fakultas Ekonomi, 1964.

[5] A. S. Mubah, "Strategi Meningkatkan Daya Tahan Budaya Lokal dalam Menghadapi Arus Globalisasi," J. Unair, vol. 24, no. 4, pp. 302-308, 2011.

[6] Sugiyono, "Metode Penelitian kuantitatif kualitatif dan R dan D," Alf. Bandung, 2010.

[7] P. Sugiyono, Metode Penelitian Kuantitatif, Kualitatif, dan R\&D. 2013.

[8] P. Sugiyono, "Dr. 2010," Metod. Penelit. Kuantitatif, Kualitatif, dan R\&D. Bandung CV Alf.

[9] I. Gunawan, "Metode Penelitian Kualitatif: Teori dan Praktik. Edisi kesatu, Cetakan keempat," PT. Bumi Aksara. Jakarta, 2016.

[10] B. A. S. Afifuddin and B. A. Saebani, "Metodologi penelitian kualitatif," Bandung CV Pustaka Setia, p. 131, 2009.

[11] A. Sugiyono, "Pengantar Statistik Pendidikan," Jakarta Graf. Persada, 2004.

[12] L. J. Moleong, Metodologi penelitian. 1999.

[13] J. W. Creswell and J. D. Creswell, Research Design: Qualitative, Quantitative, and Mixed Methods Approaches. Sage publications, 2017.

[14] S. Nasution, Berbagai pendekatan dalam proses belajar dan mengajar. PT. Bina Aksara, 2000.

[15] K. G. Esterberg, "Qualitative methods in social research," 2002.

[16] J. Lofland and L. H. Lofland, "Analyzing social settings," 1984.

[17] M. B. Milles, "Huberman. 1984. Qualitative Data Analysis." London: Sage Publication. 